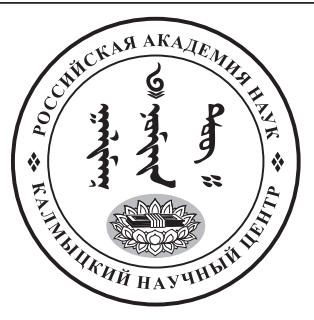

Published in the Russian Federation

Oriental Studies (Previous Name: Bulletin of the Kalmyk Institute

for Humanities of the Russian Academy of Sciences)

Has been issued as a journal since 2008

ISSN: 2619-0990; E-ISSN: 2619-1008

Vol. 13, Is. 3, pp. 629-639, 2020

DOI: $10.22162 / 2619-0990-2020-49-3-629-639$

Journal homepage: https://kigiran.elpub.ru

UDC $294.321+930.253$

DOI: 10.22162/2619-0990-2020-49-3-629-639

\title{
Два «Царя дхармы» одного текста наставлений
}

\section{Баазр Александрович Бичеев ${ }^{1}$}

${ }^{1}$ Калмыцкий научный центр РАН (д. 8, ул. И. К. Илишкина, 358000 Элиста, Российская Федерация) доктор философских наук, ведущий научный сотрудник

iD 0000-0002-9352-7367. E-mail: baazr@mail.ru

(C) КалмНЦ РАН, 2020

(C) Бичеев Б. А., 2020

Аннотация. Введение. «История Усун Дебескерту-хана» - один из интересных памятников старописьменной ойратской литературы. О его популярности и широкой распространенности свидетельствуют многочисленные списки этого произведения, хранящиеся в научных фондах России, Монголии и Китая. Содержание текста состоит из наставлений, приписываемых тибетскому царю Ралпачану, который был последним «царем дхармы» древней династии царей Тибета. За время своего правления он сумел укрепить государственность страны, избавить ее от протектората Китая и утвердить буддизм в качестве государственной религии. Косвенно эти события нашли свое отражение в тексте его наставлений. Однако это произведение было создано не при его жизни, а гораздо позже - в XV в. C кончиной Ралпачана в древнем Тибете завершилась эпоха «религиозных царей» и начался распад страны на мелкие княжества. Процесс активного возрождения и реформации буддизма начнется лишь с XV в. и был связан с деятельностью Цонкапы и появлением института Далай-лам. В XV в. и был составлен текст наставлений Ралпачана. В середине XVII в. этот сборник наставлений был переведен на ойратский язык ойратским правителем Гуши Номин-ханом, который в свое время также был признан в Тибете «царем дхармы». Это обстоятельство позволяет взглянуть на появление ойратского перевода этого произведения с точки зрения происходивших в середине XVII в. исторических событий в Тибете и Джунгарии, а также раскрыть его историческое содержание. Так в пространстве текста одного наставления, известного в литературе монгольских народов под названием «История Усун Дебескерту-хана», оказались связаны имена двух «царей дхармы» и две эпохи тибетского буддизма. Цель статьи - введение в научный оборот ойратского текста «Истории Усун Дебескерту-хана» и анализ его исторического содержании. Решаемье задачи: определить историческую составляющую содержания произведения. Основной метод исследования - историко-сравнительный анализ произведения. Новизна работыл. Несмотря на неоднократную публикацию текста, анализ исторического аспекта содержания произведения не осуществлялся. Результаты исследования: наставления тибетского царя Ралпачана основаны на «двух правилах», которые были окончательно утверждены в период его правления; религиозные и светские нормы, провозглашаемые в произведении, свидетельствуют об утвержде- 
нии буддизма в Тибете как государственной религии; перевод наставлений тибетского царя Ралпачана на ойратский язык ойратским правителем Гуши Номин-ханом является своеобразным признанием его «царем дхармы». Заключение. Анализ содержания текста «Истории Усун Дебескерту-хана» и сопоставление с данными тибетских и ойратских летописей позволили раскрыть историческое содержание произведения.

Ключевые слова: Усун Дебескерту-хан, наставления, автор, переводчик, царь Ралпачан, джунгарский правитель Гуши Номин-хан, «царь дхармы»

Благодарность. Исследование проведено в рамках государственной субсидии — проект «Устное и письменное наследие монгольских народов России, Монголии и Китая: трансграничные традиции и взаимодействия» (номер госрегистрации: АААА-А19-119011490036-1).

Для цитирования: Бичеев Б. А. Два «Царя дхармы» одного текста наставлений // Oriental studies. 2020. T. 13. № 3. C. 629-639. DOI: 10.22162/2619-0990-2020-49-3-629-639

UDC $294.321+930.253$

DOI: $10.22162 / 2619-0990-2020-49-3-629-639$

\title{
Two 'Dharma Kings' of One Didactic Text
}

\author{
Baazr A. Bicheev ${ }^{I}$
}

${ }^{1}$ Kalmyk Scientific Center of the RAS (8, Ilishkin St., Elista 358000, Russian Federation)

Dr. Sc. (Philosophy), Leading Research Associate

iD 0000-0002-9352-7367.E-mail: baazr@mail.ru

(C) KalmSC RAS, 2020

(C) Bicheev B. A., 2020

\begin{abstract}
Introduction. The Story of Usun Debeskertu Khan is a notable monument of old Oirat literature. Its popularity and wide distribution are evidenced by numerous manuscript copies stored by scientific institutions of Russia, Mongolia and China. It consists of instructions attributed to the Tibetan King Tri Ralpacan referred to as the last 'Dharma King' of the ancient royal dynasty of Tibet. During his reign, he was able to strengthen the country's nationhood, dismiss China's protectorate, and get Buddhism established as the state religion. Indirectly, these events are reflected in the text of his homilies. However, this work was created not during his lifetime but much later - in the $15^{\text {th }}$ century. Ralpacan's death marked the end of the era of 'religious kings', and the country started disintegrating into a vast number of small principalities. The process of active revival and reformation of Buddhism would begin only in the $15^{\text {th }}$ century directed by Je Tsongkhapa and further sustained by the emerged institution of the Dalai Lamas. And it is during this period that the book of Ralpacan's homilies was compiled. In the mid- $17^{\text {th }}$ century, those were translated into Oirat by the famous Khoshut ruler Güshi Nomin Khan recognized in Tibet as a 'Dharma King'. This circumstance makes it possible to consider the creation of the Oirat translation from the viewpoint of historical events that were taking place in the mid- $17^{\text {th }}$ century in Tibet and Dzungaria, as well as to reveal its actual contents. So, a textual space of one didactic text known in Mongolic literatures as The Story of Usun Debeskertu Khan connects names of two great 'Dharma Kings' — and two epochs of 'religious kings' of Tibetan Buddhism. Goals. The article seeks to introduce the Oirat text of The Story into scientific circulation, and analyzes its historical contents identifying the historical component of the work. Methods. Comparative historical analysis proves a key research method. Despite repeated publications of the text, the latter was never essentially analyzed for historical aspects. Results. And the analysis conducted shows that 1) Tibetan King Ralpacan's homilies are based on the 'two principles (guidelines)' finally adopted in his era, 2) religious and secular norms proclaimed by the text attest to that Buddhism had been thus established as the state religion of Tibet, 3) the fact the text of Tibetan King Ralpacan's homilies was translated into Oirat by Güshi Nomin Khan implies the latter should be equally revered as a 'Dharma King'.
\end{abstract}

Keywords: Usun Debeskertu Khan, instruction, author, translator, King of Tibet Ralpacan, Dzungar ruler Güshi Nomin Khan, 'Dharma King' 
Acknowledgements: The reported study was funded by government subsidy — project name 'Oral and Written Heritage of Mongolic Peoples of Russia, Mongolia and China: Cross-Border Traditions and Interactions' (state reg. no. AAAA-A19-119011490038-5).

For citation: Bicheev B. A. Two 'Dharma Kings' of One Didactic Text. Oriental studies. 2020. Vol. 13(3): 629-639. (In Russ.). DOI: 10.22162/2619-0990-2020-49-3-629-639

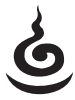

\section{Введение}

Удивительные метаморфозы памяти делают одни литературные творения, содержание которых непосредственно связано с эпохальными событиями времени их создания, исторически значимыми, а другие - забытыми. Судьба такого произведения складывается самым неожиданным образом. По истечении долгого времени со дня своего появления оно неожиданно обретает новую жизнь, но события, вызвавшие этот ренессанс, оказываются сходными с событиями, предшествовавшими рождению этого текста. И если не учесть этой опосредованно существующей исторической связи, то причина последующей широкой популярности текста может трактоваться лишь исходя из его непосредственного содержания, что не всегда дает возможность раскрыть реальную историческую атмосферу, которая сопровождала рождение текста. С подобным явлением исследователи сталкиваются при знакомстве с известным и широко распространенным во второй половине XVII столетия произведением старописьменной ойратской литературы «История Усун Дебескерту-хана» («Üsün debeskertü xāni tuuјi orošiboi»).

O популярности этого произведения еще в недавнем прошлом свидетельствует упоминание о нем в работах исследователей начала прошлого столетия [Очиров 1910; Очиров 1913].

Широкая распространенность рукописных списков текста подтверждается и достаточно большим количеством рукописей, хранящихся как в личных коллекциях [Цэвгээ 2003], так и в научных фондах России [Орлова 2002; Сазыкин 1988; Uspensky 1999], Монголии [Оюу чихт 2005; Gerelmaa 2005] и Китая [Galdan 2013].

По данным существующих каталогов монгольских рукописей, на сегодня известно о тринадцати списках этого произведе- ния на ойратском «ясном письме» [Бичеев 2019].

«История Усун Дебескерту-хана» представляет собой перевод тибетского произведения, состоящего из наставлений, приписываемых тибетскому царю, имя которого на ойратском языке обозначено как Усун Дебескерту-хан. К сожалению, нам не известен тибетский оригинал текста, с которого в середине XVII столетия был сделан его ойратский перевод. Однако текст, судя по его содержанию, представлял собой традиционную для тибетской литературы форму «личных наставлений», которые слагались из поучений от лица царя на разные темы и были адресованы всем подданным [Востриков 2007: 48].

В названии одной из рукописей на «ясном письме» указано, что это «Наставления Усун Дебескерту-хана и двенадцати его министров» («Üsün debeskertü xān arban xоyor tüšimed-lügē ögüüleqsen yoson orošibai») [Цэвгээ 2003: 95].

«Царь дхармы» - автор «Истории Усун Дебескерту-хана»

Во всех известных списках рукописей на «ясном письме» авторство этого сборника наставлений и поучений приписывается Усун Дебескерту-хану. За этим именем скрывается представитель древней династии тибетских царей Тицуг Децэн (Khrigtsug lde-bstan) или Три Ралпачан (Ral-pa$(a n)^{1}$. K сожалению, нам не известен тибетский оригинал этого сборника наставлений, с которого осуществлялся ойратский перевод, но можно предположить, что Усун Дебескерту-хан ойратского текста - это и есть царь Ралпачан. Чтобы привести свидетельство в пользу нашего предположения, приведем некоторые известные факты из биографии этого тибетского правителя.

\footnotetext{
${ }^{1}$ В разных источниках имя написано по-разному: Ралбачжан [Востриков 2007], Ралпачан [Пагсам-Джонсан 1991], Рэлпачан [Шакабпа 2003].
} 
Сведения о царе Ралпачане (815-841) сохранились в тибетской исторической литературе [Востриков 2007; Пагсан-Джонсам 1991; Tuсci 1950]. Автор исторического сочинения «Пагсам-Джонсан» Сумба-кханбо Ешей Бальджор (1704-1788) приводит сравнительные данные о древних царях Тибета, в том числе и о Ралпачане. Из этих данных следует, что известный историограф, настоятель монастыря Шалу Будон Ринчендуб (1290-1364) в своем труде «История буддизма» пишет, что «Ралпачан, года огня-собаки рождения (806 г.), в 18 лет встал во главе царской власти; в 36 лет, в год железа-курицы (841 г.), был убит министром» [Пагсам-Джонсан 1991: 24].

Иерарх школы Сакья Пагба-лама (1235-1280) в своем сочинении «Родословная царей Тибета» отмечает, что «Тидэ-Сронцзан, года дерева-дракона рождения (824 г.), с 24 до 54 лет, до года огня-курицы (877 г.), и Ралпачан, года огня-собаки рождения (866 г.), с 12 до 36 лет, до года железа-курицы (901 г.) были царями» [Пагсам-Джонсан 1991: 25].

Выдающийся тибетский историк Гой-лоцзава Шоннупэл (1392-1481) в своем труде «Синяя книга. История буддизма» считает, что Ралпачан с года дерева-лошади (874 г.) правил 23 года [Пагсам-Джонсан 1991: 26].

Наконец, Далай-лама V Нгаванг Лобсан Гьяцо (1617-1682) пишет, что «самый младший из сыновей Садна-Лэга Тидэ-Сронцзан-Ралпачан был года огня-собаки рождения (806 г.). Во время становления его хозяином царской власти противоречия с Китаем были преодолены: в честь этого был возведен каменный обелиск и установлена власть „двуединая“. Он был убит в год железа-курицы (901г.)» [Пагсам-Джонсан 1991: 26].

Сопоставив все эти данные, Сумба-кханбо Ешей Бальджор приходит к выводу о том, что «Ралпачен, года огня-собаки рождения (806 г.), с года огня-курицы (877 г.) выдвинулся в цари и был убит в год огня-дракона (896 г.)» [Пагсам-Джонсан 1991: 32].

Из работ современных исследователей, которые использовали труды вышеуказанных и других тибетских авторов, известно, что отец Ралпачана Саналег (800-815) вступил на трон молодым человеком [Шакабпа 2003: 62]. Управлять государством ему по- могали четыре министра - Дэнка Пэлгьи Йонтэн, Ньянг Тингзин, Шанг До Тисур и Нанам Тридаг-гьел. При этом двое первых имели звание банди, поскольку были буддийскими монахами. Эти же сановники впоследствии будут участвовать в управлении государством и при Ралпачане. Во всяком случае, Шакабпа пишет, что буддийский монах банде Дэнка Пэлгьи Йонтэн был главным министром государства [Шакабпа 2003: 62]. Видимо, они и являются теми четырьмя из двенадцати сановников, которые присутствовали при утверждении наставлений Усун Дебескерту-хана в виде общепринятых светских и религиозных норм.

В период правления Саналега «были приглашены индийские пандиты, чтобы помочь в переводе буддийских текстов. Саналег построил недалеко от Лхасы храм Карчунг Лхаканг. Поскольку в это время буддийская религия испытывала противодействие, царь созвал на совет своих министров и разных вассалов со всех частей царства. Был составлен обширный документ, обещавший поддержку распространению буддийской веры, подписанный царем и всеми, кто присутствовал. Также на колонне перед Карчунг Лхакангом была выбита надпись, посвященная этой акции» [Шакабпа 2003: 62].

Известно, что у Саналега было пять сыновей, старший из которых стал монахом, а два последних умерли. Когда в 815 г. Саналег умер, на престол вступил «Тидэ-Сронцзан-Ралпачан, года огня-собаки рождения (866 г.)» [Пагсам-Джонсан 1991: 19]. Министры пренебрегли его братом Дармой, поскольку он испытывал неприязнь к буддизму и был вспыльчивым человеком [Шакабпа 2003: 62].

И. Попов пишет о том, что в первые годы своего царствования Ралпачан вел удачные войны с Китаем и возвратился в Тибет с огромной добычей, «так что слава о его могуществе и силе восходила до тенгриев» [Попов 2001: 56]. Китай был вынужден подписать с ним мирный договор. В честь этого события «на трех высоких каменных плитах составили клятвенный договор и прочее, благодаря чему в Тибете /договор/ оказался весьма полезным» [Пагсам-Джонсан 1991: 19-20].

Известно, что одна плита была поставлена перед воротами императорского двор- 
ца в Китае, другая — на границе двух стран, а третья - перед главными воротами храма Джоканг в Лхасе. Цепон Шакабпа пишет, что, видимо, этим было обусловлено и то, что эпоха правления Ралпачана под влиянием китайской традиции была обозначена именем «sKyi rtag» (sKyi rtag; перевод термина в работе не приводится). Это единственный такой случай в ранней истории Тибета [Шакабпа 2003: 347].

При Ралпачане в Тибет прибыли индийские знатоки и комментаторы буддийского канона - ученые-пандиты Данашила, Джинамитра и Шилендрабодха. Вместе с двумя известными тибетскими переводчиками Каву Пэлцег и Чогро Луй Гьелцэном они сформировали комиссию переводчиков, которая выработала нормы перевода буддийских терминов с санскрита на тибетский язык и составила первый санскритско-тибетский словарь буддизма «Махавьюпати» [Востриков 2007: 101; Попов 2001: 56-57; Шакабпа 2003: 63].

При Ралпачане было построено большое количество новых буддийских храмов, на строительство которых были привлечены опытные каменщики, плотники, кузнецы и мастера серебряных дел Китая, Непала и Туркестана [Шакабпа 2003: 64]. Для стимулирования роста монашеской общины, Ралпачан утвердил положение, согласно которому семь домовладений должны были обеспечивать содержание одного монаха. Для поднятия авторитета монахов было приказано называть их «священнослужителями царской головы». Это обращение к монахам возникло в связи с обычаем «привязывать длинные тесемки к волосам Ралпачана, к которым затем прикреплялась ткань. Затем эта ткань раскладывалась на полу, и монахи садились на нее, когда молились, или ели перед царем. Этому обычаю следовали только тогда, когда какой-либо монах был гостем царя, который иногда мог находиться в соседнем помещении [Шакабпа 2003: 64].

Эта традиция объясняет нам значение имени Ral-pa-can (ralpa 'волосы'; can 'обладающий'). В буквальном ойратском переводе это имя передано в форме Üsün debeskertü xān (üsün 'волосы'; debesker 'подстилка'; букв. 'Имеющий подстилкой волосы').

В монгольских исторических сочинениях имя Ral-pa-can известно как Üsün sandal- tu qayan (букв. üsün 'волосы'; sandal 'стул'; букв. 'Имеющий стулом волосы') [Алтан товчи 2001: 146].

Традиция буквальной передачи санскритских и тибетских имен - одна из норм переводов тибетских сочинений. К примеру, в ойратском переводе «Сутры Золотого света» («Altan gerel») из 150 собственных имен большинство является буквальной передачей с тибетского языка или санскрита [Yakhontova 2018: 394-406].

Лишенный трона, старший брат Ралпачана Дарма с помощью интриг сумел отправить своего брата-монаха в далекий Бутан и заставил поверить Ралпачана в любовную связь его супруги с главным министром государства Дэнка Пэлгьи Йонтэном. Монах-министр был изгнан в глухую местность, где и был убит во время медитации. В 836 г. Ралпачан был задушен двумя своими министрами, которые незадолго до этого убили оклеветанного ими главного министра государства. На трон взошел его брат Дарма, абсолютно не питавший любви к буддизму.

Со смертью Ралпачана, по мнению исследователей, завершился первый этап утверждения буддизма в качестве государственной религии в Тибете. Сумба-кханбо Ешей Бальджор пишет, что из всех линий тибетских царей, «исключая Дарму, все, начиная от Сронцзана и ниже, веровали в Три драгоценности» [Пагсам-Джонсан 1991: 23]. В истории Тибета Ралпачан признан третьим «царем дхармы», вслед за Сронцзан-гампо и Трисонг Деценом, при которых буддизм получил развитие в Тибете.

Именно в период правления Ралпачана произошел процесс концентрации в руках правителя страны «двуединой» власти (религиозной и светской: chos srid gnyis ka), т. е. официального признания буддизма государственной религией Тибета.

Итак, можно выделить те исторические достижения Тицуг Децэна или Ралпачана, которые ему удалось воплотить за время его правления - укрепление государственности Тибета, избавление страны от протектората Китая и утверждение буддизма в качестве государственной религии.

Косвенно эти события нашли свое отражение в художественной форме во вступительной части «Истории Усун Дебескерту-хана». 


\begin{tabular}{|c|c|}
\hline 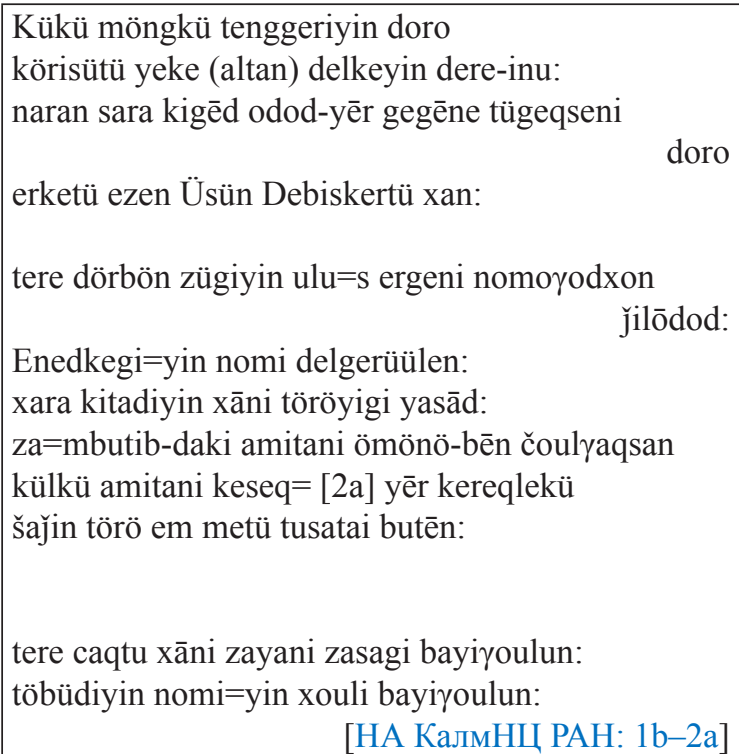 & $\begin{array}{l}\text { Под Вечно синим небом, } \\
\text { На златокорой земле, } \\
\text { Под льющимся сиянием солнца, луны } \\
\text { Властитель Усун Дебескерту-хан, } \\
\text { Управляя подданными четырех сторон } \\
\text { Распространил Дхарму Индии, } \\
\text { Упразднил власть хана черных китайцев, } \\
\text { Собрал пред собой людей Джамбутвипы, } \\
\text { Для долгого употребления всеми [2а] } \\
\text { Установил государство, подобное } \\
\text { полезному лекарству, } \\
\text { Утвердил предназначенную власть хана } \\
\text { И закрепил законы тибетской Дхармы. } \\
\text { (Перевод наш. - Б. Б.) }\end{array}$ \\
\hline
\end{tabular}

Таким образом, в «Истории Усун Дебескерту-хана» нашли отражение те исторические события, которыми ознаменовалась эпоха правления «царя дхармы» Ралпачана. Однако его наставления вряд ли могли быть составлены при его жизни и даже не сразу после его смерти, поскольку вслед за вступлением на трон его брата Дармы последовали гонения на буддизм. Затем последовал распад страны на мелкие княжества, завершивший эпоху «религиозных царей» (чойгел), последним из которых и был «царь дхармы» Ралпачан.

Процесс активного возрождения и реформации религиозной традиции начнется лишь в XV столетии с деятельностью «второго Будды» Цонкапы (1357-1419) и появлением института Далай-лам. Известно, что популярный памятник тибетской апокрифической литературы «Мани-гамбум», представляющий собой собрание произведений, приписываемых первому «царю дхармы» Сронцзан-гампо (617-698), по данным исследователей, был составлен только в XV в. [Востриков 2007: 44; Rockhill 1891]. По всей видимости, подобно этому, и поучения Ралпачана были составлены в этот же период времени.

\section{«Царь дхармы» - автор перевода «Истории Усун Дебескерту-хана»}

Ойратский перевод «Истории Усун Дебескерту-хана» был осуществлен в середине XVII в. Такой вывод позволяет сделать колофон переводчика, который присутствует во всех известных нам списках этого произведения. Из содержания колофона следует, что автором наставлений является тибетский царь Ралпачан (Üsün debeskertü xān), переводчиком произведения с тибетского языка назван Арьядева Гуши (aryādevā Güüši), a инициатором перевода - Кундулен Хурмуста-хан (Kündölöng Xurmusta xān).

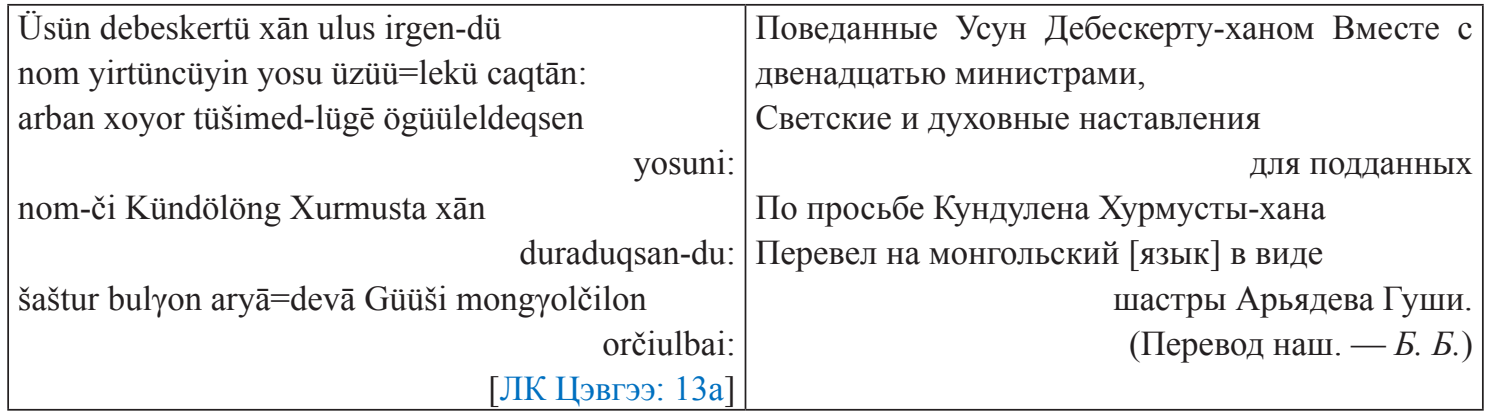

Во всех тринадцати известных списках этого текста на «ясном письме» в содержа- нии колофона нет заметных расхождений. За исключением написания, пропусков или 
замены некоторых слов. К примеру, в одном из колофонов вместо «aryādevā Güüši» написано «akdivā Güüši», вместо «Kündölöng Xurmusta xān» — «Kündölöng Xurmusta».

Названный в колофоне переводчик Арьядева Гуши (aryādevā Güüši) — это один из ойратских предводителей Гуши Номин-хан, который, подобно великим правителям древности, был признан в Тибете как «дхарма-раджа» (тиб. chos rgyal, чойжал - царь Дхармы) и «держатель Учения» (тиб. bstan 'dzin, данцзин 'держатель Учения').

Сумба-кханбо Ешей Бальджор пишет, что в 1637 г. «дхарма-раджа Гуши прибыл в Куку-нор, разгромил халхаского Цогту /-тайчжи/ с войсками, которые были враждебны к религии гэлукпа» [Пагсам-Джонсан 1991: 129].

В 1642 г. «Данцзин-Чойжал /Гуши-хан/ прибыл в Цзан, захватил цзанского царя, сокрушавшегося /о потере/ лучших земель, подчинил своей власти Цзан и Камон и стал тибетским царем» [Пагсам-Джонсан 1991: 129].

События, связанные с походом ойратов в Тибет и утверждением власти хошетовского Гуши-хана, достаточно подробно освещены в работах отечественных и зарубежных исследователей [Златкин 1983; Кычанов, Мельниченко 2005; Попов 2001; Шакабпа 2003].

Инициатором перевода этого произведения указан Кундулен Хурмуста-хан (Kündölöng Xurmusta xān) — это брат Гуши-хана, известный в истории ойратов как Кундулен Убаши, а также Дургегчи нойон Убаши. О нем, как и о других его четырех братьях, которых называли «пять хошеутовских братьев-барсов» («хошудин ах тавн бар»), в памяти народа сохранились предания исторического содержания.

Составитель первой калмыцкой хрестоматии, учитель народной школы Ш. Болдырев приводит одно из этих преданий.
Хошудин Хан нойн Хоңһр тавн көвүтә сәнж.
Эдниг тавн барс гиж нерәдсн. Эднә негнь -
Көндлң Увш. Эн нойн Дүүргәж нойн Увш гиж
нер хальдсн болдг.

Гүши Номин хан - Хан нойн Хоңһрин дөрвдгч көвүн. Көндлң Увш Бәәвһәс хан хойрин дү. Гүши Номин хан шарин шажнд хәәрслтә гидгәрн алдршсн. Бийнь ик сүзгч хан сәнж. Шарин шажиг сәәнәр бәрж, Зунквад шүтж, теднә һарһсн тоот цуһариг күцәдг санж болсар, маңнань арсн шулврад шархдтлан олн һазрт күргж мөргдг сәнж.

Гүши Номин хааг төвд келнәс моңһл келнд «Алтн герл» орчулсн гиж келдг.

[Калмыцкая хрестоматия 1927: 155-156]

Итак, переводчик сочинения Арьядева Гуши (aryādevā Güüši) — это предводитель хошеутов Гуши Номин-хан. Его монгольское имя - это калька санскритского Дхарма-раджа, тибетского Чойжал - Номин хан, а тибетское Данцзин передано как «Гуши» — «высокородный, святой». Его настоящее имя - Тур Байху. «Третий из пяти сыновей Ханы, владетельного князя хошодов (хошутов) из среды четырех хошунов ойратов, перерожденец дхарма-раджи Ямандаки, у которого настоящее имя было Торал-Баху и
Хошеутовский хан-нойон Хонгор имел пять сыновей, которых называли «пять братьев-барсов». Один из них - Кундулен Убаши. Он также известен под именем Дургегчи нойон Убаши.

Гуши Номин-хан - четвертый сын Хан-нойон Хонгора. Он был младшим братом Кундулен Убаши и Байбагас-хана. Гуши-хан прославился как ревностный буддист, будучи глубоко верующим человеком. Он строго придерживался учения, почитал Цонкапу и следовал всем религиозным обетам. Он так усердно бил поклоны в святых местах, что на лбу у него образовалась рана.

Говорят, что Гуши Номин-хан перевел на монгольский язык «Сутру Золотого света».

(Перевод наш. - Б. Б.)

которого тибетцы называли Данцзин-Чойжал, а монголы - Гуйшри-хан или Гэкэнхан, в 13 лет захватил Гокар, в 20 лет уладил распри между олетами и халхасцами» [Пагсам-Джонсан 1991: 46].

Сумба-кханбо Ешей Бальджор в своем труде дает идеализированный образ «царя дхармы» Гуши Номин-хана как правителя, обладавшего «двуединой» властью, как объекта почитания и как духовного практика. «Цари Индии, Непала и Нгарийя и другие преподнесли /Гуши-хану/ 
богатые дары, тибетцы прославляли его как перерожденца учителя Бадма-Самбхавы. ... Этот дхарма-раджа обеспечил процветание благоденствию подвластных ему монастырей, министров и вплоть до подданных с позиции преодоления соперничества между духовным и светским правлениями... Он же узрел лики Маньчжушри и Цзонхапы...» [Пагсам-Джонсан 1991: 47-48].

Сведения о том, что Гуши Номин-хан был не просто ревностным практиком буддийского учения, но еще и занимался переводами буддийских сочинений, - дополнительное подтверждение авторства его перевода наставлений царя Ралпачана. И если о его переводе «Сутры Золотого блеска» пока не удалось обнаружить подтверждающих данных, то его ойратский перевод «Истории Усун Дебескерту-хана» имел достаточно широкое распространение в монгольском мире. Согласно историческим данным, Гуши-хан умер в 1654 г. Исходя из этого, можно предположить, что перевод «Истории Усун Дебескерту-хана» мог быть выполнен до этой даты и на «ясном письме», которое было создано в 1648 г.

Выбор именно этого сочинения для его перевода, как нам представляется, не был случайным. И выбор осуществлялся не самим Гуши Номин-ханом, а теми буддийскими учителями, которые, во-первых, имели на него определенное влияние и, во-вторых, прекрасно осознавали, что авторство перевода наставлений, приписываемых древнему царю Ралпачану, могло иметь огромное значение для еще большего укрепления авторитета Гуши Номин-хана как «царя дхармы» среди тибетцев, связывая его имя с именем легендарного «царя дхармы» Ралпачаном. Понимали они и то, что имя Гуши Номин-хана в качестве переводчика наставления, как и имя Кундулен Убаши, прославившегося среди ойратов своей мудростью и богатырской силой, в качестве инициатора перевода, несомненно, будут способствовать популярности этого произведения и послужат укреплению учения Будды в их умах и сердцах.

Думается, что был и еще один не менее важный практический интерес для выбора этого произведения в качестве перевода. Доступность содержания текста и его широкая адресность должны были способство- вать популяризации и закреплению недавно созданного «ясного письма» в широких слоях ойратского общества.

Если исходить, что именно такие цели предполагались при выборе этого сочинения для перевода, то тем, кто мог указать Гуши Номин-хану на выбор именно этого произведения, мог быть лишь сам основатель ойратской письменности Зая-пандита Намкаджамцо. Для человека, который, начиная с 16 лет, провел в обучении больше двадцати лет в Тибете и получил высшую ученую степень рабджамбы, выбор этого сочинения, перевод которого имел бы как политический, так и религиозный резонанс в сложившейся исторической ситуации, был очевидным.

Авторитет Зая-пандиты в широкой среде ойратского общества и в среде правящей и духовной элиты Джунгарии и Тибета был не меньшим, чем у Гуши Номин-хана. К тому же Зая-пандита был не просто соплеменником хошеутовского правителя, но и приходился ему племянником, поскольку официально был усыновлен его старшим братом Байбагас-ханом. При этом Зая-пандита был не только духовным главой Джунгарии, но и официальным представителем Далай-ламы и Панчен-ламы в Джунгарии. Именно с этой его обязанностью связаны его неоднократные поездки в Тибет.

По всей видимости, «темное» место в книге Шакабпы, относительно ответа Далай-ламы $\mathrm{V}$ на приглашение Гуши-хана посетить его страну, сделанное им в 1638 г. связано с Зая-пандитой. «Не имея возможности оставить свои обязанности, Далай-лама направил в Монголию своего постоянного представителя поддерживать хорошие отношения с монголами» [Шакабпа 2003: 118]. Известно, что в 1639 г. Зая-пандита по указанию Панчен-ламы и Далай-ламы вернулся на родину в Джунгарию.

Таким образом, сборник наставлений «История Усун Дебескерту-хана», составленный тибетскими монахами в XV в., но приписываемый царю Ралпачану, жившему в IX в., был переведен в середине XVII в. на ойратский язык «царем дхармы» ойратским Гуши Номин-ханом и получил широкое распространение в монгольском мире. Так в пространстве одного текста дидактического содержания, известного в литературе мон- 
гольских народов под названием «История Усун Дебескерту-хана», оказались связаны имена двух «царей дхармы».

\section{Заключение}

У сборника наставлений известного под названием «История Усун Дебескерту-хана» достаточно интересная литературная судьба. Авторство этого произведения приписывается тибетскому правителю древней династии, «царю дхармы» Ралпачану, временем правления которого завершилась эпоха «религиозных царей» древнего Тибе-

\section{Источники}

ЛК Цэвгээ - Личная коллекция Н. Цэвгээ (Монголия, Ховд аймак, сомон Жаргалант). Üsün debeskertü xān arban xoyor tüšimed-lügē ögüüleqsen yoson orošibai. Ойр. рук., 13 л., $22 \times$ 7.7, 27 стк., потемневшие листы, черная тушьъ.

НА КалмНЦ РАН - Üsün debiskertü xāni nomloqson šaštir kemekü orošiba. Ойp. рук., 17 л., 21,5x8, 20-21 стк., бумага серая, тушь черная, перо // НА КалмНЦ РАН. Ф. 15. Оп. 3. Ед. хр. 148.

\section{Литература}

Алтан товчи 2011 - Лувсанданзаны зохиосон. Эртни хаадын үндэслэсэн төр ёсны зохиолыг товчлон хураасан Алтан товч хэмээх оршвой. Эх бичгийн цогц судалгаа хийсэн доктор (Sc. D), профессор Шаравын Чоймаа (= Лувсанданзан. Краткий свод сведений о древних монгольских ханах «Алтан товчи». Исследование текста памятника проф. Шаравын Чоймы). Улаанбатар: «Болор судар» хэвлэлий газар, 2011. 762 х.

Востриков 2007 - Востриков А. И. Тибетская историческая литература. СПб.: Петербургское востоковедение, 2007. 336 с.

Бичеев 2019 - Бичеев Б. А. Списки рукописей и история публикации «Истории Усун Дебескерту-хана» // Oriental Studies. 2019. № 3. C. 441-449.

Оюу чихт 2005 - Оюу чихт хаан хөвүүний тууж тэргүүтэн монголын сонгодог уран зохиолын хэдэн дурсгал (= «История принца Ою Чихтэ» и другие избранные произведения монгольской литературы). Улаанбаатар: Coёмбо Принтинг ХХК, 2005. 101 с.

Златкин 1983 - Златкин И. Я. История Джунгарского ханства. 1635-1758. Изд. 2-е. М.: ГРВЛ, Наука, 1983. 331 с.

Калмыцкая хрестоматия 1927 - Калмыцкая та, начался распад государства и гонения на буддизм. Поэтому наставления, приписываемые Ралпачану, могли быть составлены лишь в XV в., когда в Тибете началась реформаторская деятельность Цонкапы и утвердился институт Далай-лам.

В середине XVII в. сборник наставлений Ралпачана был переведен на ойратский язык известным в истории Тибета «царем дхармы» ойратским правителем Гуши Номин-ханом и получил широкое распространение в письменном виде среди монгольских народов.

\section{Sources}

Üsün debeskertü xān arban xoyor tüšimed-lügē ögüüleqsen yoson orošibai: The Story of Usun Debeskertu Khan. Oirat manuscript. At: personal collection of N. Tsevgee. 13 p. (In Oir.)

Üsün debiskertü xāni nomloqson šaštir kemekü orošiba: The Story of Usun Debeskertu Khan. Oirat manuscript. At: Scientific Archive of the Kalmyk Scientific Center of the RAS. 17 p. (In Oir.)

хрестоматия для чтения в аймачных и в младших отделениях улусных школ / сост. Ш. Болдырев // Хонхо. Вып. III. Прага: Изд. КККР в ЧСР, 1927. 255 с.

Кычанов, Мельниченко 2005 - Кычанов Е. И., Мельниченко Б. Н. История Тибета с древнейших времен до наших дней. М.: Вост. лит., 2005. 351 с.

Орлова 2002 - Орлова К. В. Описание монгольских рукописей и ксилографов, хранящихся в фондах Калмыкии // Бюллетень Общества востоковедов. Вып. 5. М.: Институт востоковедения РАН; Калмыцкий институт гуманитарных исследований РАН, 2002. 85 с.

Очиров 1910 - Отчет о поездке Н. Очирова к Астраханским калмыкам летом 1909 года // Известия Русского комитета для изучения Средней и Восточной Азии. СПб., 1910. Март. С. 61-75.

Очиров 1913 - Поездка в Александровский и Багацохуровский улусы Астраханских калмыков. Отчет H. Очирова // Известия Русского комитета для изучения Средней и Восточной Азии. СПб., 1913. Сер. II, № 2. С. 78-91.

Пагсам-Джонсан 1991 - Пагсам-Джонсан: История и хронология Тибета. Перевод с тиб. языка, предисловие, комментарий $P$. E. 
Пубаева. Новосибирск: Наука, СО РАН, 1991. $261 \mathrm{c}$.

Попов 2001 - Попов И. История Тибета // Bce о Тибете. М.: Полиграфист, 2001. С. 31-98.

Сазыкин 1988 - Сазыкин А. Г. Каталог монгольских рукописей и ксилографов Института востоковедения АН СССР. Т. І. М.: Наука; ГРВЛ, 1988. 507 с.

Цэвгээ 2003 - Цэвгээ Н. Ойрадад анх шарын шашин үүссэн, соёл, нийгэм төрийн хувьсал (= Принятие буддизма ойратами и эволюция культуры и общества). Улаанбаатар: [б. и.], 2003. $220 \mathrm{c}$.

Шакабпа 2003 - Цепон В. Д. Шакабпа. Тибет: политическая история. СПБ: Нартанг, 2003. $428 \mathrm{c}$.

Galdan 2013 - Galdan Do. Üsün debiskertü

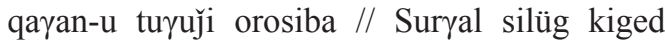
sang takil. Todu üsüg-ün erten-u dursxal bičigün sungruburi (= «История Усун Дебескерту-хана» // Стихотворные поучения и тексты воскурения. Избранные тексты памятников «ясного письма»). Ürümči: Šinǰiyang-un aradun keblel-ün xoryi-a, 2013. C. 3-19.

Gerelmaa 2005 - Gerelmaa G. Brief Catalogy of

\section{References}

Bicheev B. A. 'The Story of Usun Debiskertu': manuscript copies and history of publication. Oriental Studies. 2019. No. 3. Pp. 441-449. (In Russ.) DOI: 10.22162/2619-0990-2019-43-3441-449

Boldyrev Sh. (comp.) Kalmyk-Language Reader for Aimag- and Preliminary District-Level Schools. Ser. (journal): Khonkho. Vol. 3. Prague: Kalmyk Commission of Cultural Workers, 1927. 255 p. (In Kalm.)

Galdan Do. The Story of Usun Debiskertu Khan. In: Poetic Teachings and Incense-Offering Texts. Selected Clear Script Texts. Urumqi: Xinjiang People's Publ. House, 2013. Pp. 3-19. (In Mong.)

Gerelmaa G. Brief Catalogue of Oirat Manuscripts Kept by Institute of Language and Literature (MAS). Ulaanbaatar: Institute of Language and Literature (Mongolian Academy of Sciences), 2005. 270 p. (In Mong. and Eng.)

Kychanov E. I., Melnichenko B. N. History of Tibet: from Earliest Times to the Present Days. Moscow: Vostochnaya Literatura, 2005. 351 p. (In Russ.)

Luvsandanzan G. Altan Tobchi. Prof. Sh. Choimaa (textual research). Ulaanbaatar: Bolor Sudar, 2011. 762 p. (In Mong.)
Oirat Manuscripts Kept by Institute of Language and Literature bu Gerelmaa Guruuchin. Хэл зохиолын хүрээлэнгийн тод үсгийн номын товч бүртгэл. Ulaanbaatar: Institute of Language and Literature, Academy of Sciences of Mongolia, 2005. 270 p.

Tucci 1950 - Tucci G. The Tombs of the Tibetan Kings. Institute Italiano per II Medio Ed Estremo Oriente. Serie Orientale Roma. T. I. Roma, 1950. 117 c.

Uspensky 1999 - Uspensky $V$. Catalogue of the Mongolian Manuscripts and Xylographs in the St. Petersburg State University Library. Tokyo: Institute for the Study of Languages and Cultures of Asia and Africa, 1999. 530 p.

Yakhontova 2018 - Yakhontova N. Proper Names in the Oirat Translation of "The Sutra of Golden Light" // Philology of the Grasslands. Essays in Mongolic, Turkic and Tungusic Studies Languages of Asia. Vol. 17. Leiden; Boston, 2018. Pp. 394-429.

Rockhill 1891 - Rockhill $W$. W. The Land of the lamas. Notes of a journey through China, Mongolia and Tibet... by William Woodville Rockhill. New York: Century Co., 1891. 399 p.

Ochirov N. Aleksandrovsky and Bagatsokhurovsky Districts of Astrakhan Kalmyks: trip report. Izvestiya Russkogo komiteta dlya izucheniya Sredney $i$ Vostochnoy Azii. St. Petersburg, 1913. Ser. II. Mo. 2. Pp. 78-91. (In Russ.)

Ochirov N. Astrakhan Kalmyks, summer of 1909: trip report. Izvestiya Russkogo komiteta dlya izucheniya Sredney $i$ Vostochnoy Azii. St. Petersburg, 1910 (March). Pp. 61-75. (In Russ.)

Orlova K. V. Description of Mongolian-Language Manuscripts and Xylographs Contained in Kalmykia's Collections. Ser.: Newsletter of the (Russian) Oriental Society. Vol. 5. Moscow: Institute of Oriental Studies (RAS); Kalmyk Humanities Research Institute (RAS), 2002. 85 p. (In Russ.)

Pag Sam Jon Zang: History and Chronology of Tibet. R. Pubaev (foreword., transl., comments). Novosibirsk: Nauka, 1991. 261 p. (In Russ.)

Popov I. History of Tibet. In: A Complete Guide to Tibet. Moscow: Poligrafist, 2001. Pp. 31-98. (In Russ.)

Rockhill W. W. The Land of the Lamas: Notes of a Journey through China, Mongolia and Tibet. New York: Century Co., 1891. 399 p. (In Eng.)

Sazykin A. G. Institute of Oriental Studies, USSR Academy of Sciences: A Catalogue of Mongolian Manuscripts and Xylographs. Vol. 
I. Moscow: Nauka; GRVL, 1988. 507 p. (In Russ.)

Shakabpa W. D. Tibet: A Political History. St. Petersburg: Narthang, 2003. 428 p. (In Russ.)

The Story of Prince Oyu Chikhte and Other Selected Works Mongolian Literature. Ulaanbaatar: Soembo Printing, 2005. 101 p. (In Mong.)

Tsevgee N. Conversion of the Oirats to Buddhism: Evolution of Culture and Society. Ulaanbaatar, 2003. 220 p. (In Mong.)

Tucci G. The Tombs of the Tibetan Kings. Italian Institute of Middle and Far East. Ser.: Orientale Roma. Vol. I. Rome, 1950. 117 p. (In Eng.)

Uspensky V. Catalogue of the Mongolian Manuscripts and Xylographs in the St. Petersburg
State University Library. Tokyo: Institute for the Study of Languages and Cultures of Asia and Africa, 1999. 530 p. (In Eng.)

Vostrikov A. I. Tibetan Historical Literature. St. Petersburg: Peterburgskoe Vostokovedenie, 2007. 336 p. (In Russ.)

Yakhontova N. Proper names in the Oirat translation of 'The Sutra of Golden Light'. In: Philology of the Grasslands. Essays in Mongolic, Turkic and Tungusic Studies. Ser.: Languages of Asia. Vol. 17. Leiden; Boston 2018. Pp. 394-429. (In Eng.)

Zlatkin I. Ya. History of the Dzungar Khanate: 1635-1758. $2^{\text {nd }}$ ed. Moscow: GRVL, Nauka, 1983. 331 p. (In Russ.) 